\title{
Better Safe than Sorry - Individual Risk-free Pension Schemes in the European Union
}

\author{
Marga Peeters ${ }^{1}$ \\ Netherlands Institute for Advanced Study - Royal Netherlands Academy of Arts and Sciences \\ February 2012, Wassenaar, The Netherlands, huber@TinaMargaPeeters.eu
}

\begin{abstract}
Variations between the diverse pension systems in the member states of the European Union hamper labour market mobility, across country borders but also within the countries of the European Union. From a macroeconomic perspective, and in the light of demographic pressure, this paper argues that allowing individual instead of collective pension building would greatly improve labour market flexibility and thus enhance the functioning of the monetary union. I argue that working citizens would benefit, for three reasons, from pension saving in a risk-free savings account. First, citizens would have a clear picture of the accumulation of their own pension savings throughout their working life. Second, they would pay hardly any extra costs and, third, once retired they would not be subject to the whims of government or other pension fund managers. This paper investigates the feasibility of individual pension building under various parameter settings by calculating the pension saved during a working life and the pension dis-saved after retirement. The findings show that there are no reasons why the European Union and individual member states should not allow individual risk-free pension savings accounts. This would have macroeconomic benefits and provide a solid pension provision that can enhance mobility, instead of engaging workers in different mandatory collective pension schemes that exist around in the European Union.
\end{abstract}

Key words: pensions, labour market, monetary union.

JEL classification: G23, H55, H75, H83, J11, J26, J32, J61.

\footnotetext{
${ }^{1_{1}}$ I wish to thank the following people for useful remarks, without implicating them: an anonymous referee, Elisa Boelman, Martin M.G. Fase, Loek Groot, Petry Kievit-Tyson, André Kolodziejak and Sandra Rompelberg. I am grateful to the Netherlands Institute for Advanced Study (NIAS) for providing me with the opportunity, as a Fellow-in-Residence, to complete this paper. Comments and questions are always welcome.
} 


\section{Introduction}

One in ten European citizens has lived in more than one European Union country, usually for work reasons. Job-mobility is an indicator of the flexibility of the labour market and is vital for the well-functioning of the European Economic and Monetary Union. Nevertheless, individual workers are hampered by the patchwork of social security systems across the Union. Workers who frequently switch jobs participate in various pension schemes from different governments and pension funds and tend to lose sight of their rights and entitlements. This lack of transparency for the job-switching working EU citizen is particularly unfortunate as pension payments can amount to $30 \%$ of his gross salary.

Each of the 27 member states of the EU has its own pension system existing of a first, often second and also third pillar (see also Holzmann and Palacios, 2001). All countries have a state pension system as the first pillar, yet pension payments and pension outcomes differ. Some countries have a pay-as-you-go system as the second pillar while others have a funded system and both these systems exist in many different forms. The third pillar consists of private savings. The lack of coherence between all these different systems does not encourage labour mobility within countries and definitely hampers mobility across the EU borders.

Pension contributions are usually mandatory and collective. In most EU-countries, citizens have no direct say in how these funds are invested and can only hope that the outcome will be sufficient for their retirement. The global financial crisis of 2008-09 did not improve matters and has had a negative impact on the EU-citizens' confidence in institutional investors and Ministries of Finance as the guardians of their pension funds. In countries where pension systems depend on investment returns the situation has worsened as monetary policy has loosened, stock markets have been volatile and depressed, and the safe haven of the government bond has been under pressure. Moreover, the poor state of public finances in many EU countries casts a shadow over pension payments by governments of the future. Due to high public debt and high public deficits, state-pension payments are more under pressure than ever before. For this reason, citizens need to have a clear picture of their pension funds during their (long) working and retirement life. Individual risk-free pension schemes could provide full clarity but only under the precondition that pension savings accumulated during a working life are sufficient to cover the total pension payments throughout the estimated length of retirement life. 
This paper looks at the individual risk-free pension scheme and examines the advantages it could offer working European Union citizens who wish to cross national borders during their careers. The life plans of an average worker in the EU will be explored in terms of different parameter settings looking at: salary growth, pension savings, length of working life, number of years in retirement, the level of pension payments and the rates of return on savings. Analyses will show whether the individual risk-free pension scheme is feasible and whether the average worker would be able to make ends meet. The advantages are discussed from an average worker's point of view and from a macroeconomic perspective and examined in the light of counterarguments. Relevant literature will be cited although there is currently not much known about individual risk-free pension schemes as they do not seem to be in use except in Chile.

The outline of this paper is as follows. Section 2 discusses labour mobility in the EU from a macro point of view in-depth. Section 3 studies an individual EU-worker's income during his lifespan. Section 4 generalises the individual example given in section 3 and analyses the outcomes for pension savings under different parameter settings in order to study the pay ability of an individual worker. Section 5 summarizes the main benefits of an individual riskfree pension scheme for an individual EU worker. Section 6 gives counterarguments, asking the question why we should not be in favour of an individual risk-free pension scheme. Section 7 summarizes, concludes and gives recommendations for policy steps.

\section{The importance of labour mobility and the role of pensions}

The European Economic and Monetary Union in which seventeen economies have a common monetary policy and common currency, is in need of further economic integration. Only adjustment mechanisms in either public finance or the labour market are able to mitigate the effects of asymmetric shocks. The asymmetric shocks that hit several member states in the aftermath of the global economic crisis (2008-09) caused sovereign debt crises in Greece, Ireland and Portugal. Common monetary policy cannot be adapted to target these problem countries specifically. Exchange rates are fixed and interest rates are basically common and therefore not feasible policy instruments for countries hit by asymmetric shocks. As a consequence, in the absence of a common fiscal policy, a good functioning labour market is crucial (see also Peeters and Den Reijer, 2012; Jousten and Pestieau, 2002; Razin and Sadka, 1999). 
Quickly matching labour supply and labour demand would not increase unemployment levels and flexible wages would function as a price mechanism to match supply and demand. Excess labour supply in certain countries or regions in the EU could cancel out excess labour demand in other areas of the EU. Flexible labour-markets cushion the effects of asymmetric shocks and can absorb or even prevent future shocks. Moreover, a flexible labour market can keep wage growth moderate, which improves international competitiveness and helps in maintaining price stability. However, a precondition for flexible labour-market functioning is that people are in a position (both financially and socially) to move from one region to another and thus supply their labour.

The literature shows that labour market mobility in the EU has been low (see for instance Huber, 2004; Cavelaars and Hessel, 2007), although each EU citizen has the right to live and work in every other country in the EU. As a positive token, labour mobility within the EU is increasing (see Table 1 in Peeters, 2011; European Commission, 2011). In view of demographic developments in the EU, the expectation is that there will be more pressure to increase labour mobility in the future decades. According to the population projections of the United Nations all EU countries are ageing. In terms of the production of goods, the supply of services, but also fiscal spending on older citizens, this means less support. A decreasing group of working-age citizens will have to provide health care and other services for an increasing group of elderly. Only a flexible labour market will be able to ensure enough qualified workers are available to fill existing job vacancies. Unless working-age people, who currently do not work full-time, become fully available in the labour market place, demographic pressure will encourage more crossborder movement of workers. Temporary contracts, offering people fees to be hired rapidly, will also be conducive to the functioning of the labour market, as demand can meet supply timely. Peeters and Groot (2011) show that, in terms of labour market space availability and future fiscal expenditure on old-age pensions, among the European countries, the Czech Republic, Poland and Greece will suffer most from the aging populations.

Pensions, in particular the non-state pensions, are a major impediment to labour mobility (see European Commission, 2010a,b; Cavelaars and Hessel, 2007). In most EU countries, domestic pension portability is not easy. Switching jobs often means that the accumulated pension funds remain with the previous pension fund and are not carried over to the fund connected with the new position (see Zaidi et al., 2006; OECD, 2011; Arza and Kohli, 2008; Börsch-Supan, 2006). Between EU countries, pension portability is even more difficult, costly and sometimes impossible. Regulatory systems differ widely and switching jobs is time consuming and entails 
high administrative costs. An individual worker who changes jobs is faced with a fragmented pension fund accumulation that is located with various previous and current employer(s) (see European Commission, 2010a).

Fragmented pension savings and a lack of transparency about the outcome of future pension benefits, makes people wary. In their search for job market opportunities, they will tend to look within their own countries rather than go across the border to a neighbouring EU country unless wages are significantly higher (such as between the east and the west of the EU, for instance). A worker who is mobile and switches jobs within the EU is not only faced with huge differences in the public pension schemes, but also a wide variety of private schemes across EUcountries. Private schemes are even more varied, as some countries have mandatory and other non-mandatory schemes, again with different sizes of contributions and different associated benefit outcomes. The accumulated pension entitlements on retirement are thus a patchwork of different schemes (see Adema and Ladaique, 2009). Even if there is an overview of the pension benefits available this is not easy to understand.

From a macroeconomic viewpoint, labour mobility should be stimulated instead of hampered, so mobile workers should be rewarded not punished. As the average working lifetime is long, notably more than 40 years, people usually only start to think about the effective result of their pension funds at a late stage. At that point in life, it is often more difficult to catch-up with lost or low savings. If the accumulated savings do not suffice for covering, let us say, 30 years after retirement from the labour market, the worker could seek opportunities to replenish the funds. Finding another job with a better salary or working more hours is generally easier for younger workers who are more flexible.

In the literature, researchers discuss the problems workers have in adapting to a different cultural environment or housing as the obstructions to labour market mobility within the EU. But adapting pensions would be a more effective policy instrument as this can be implemented by policy makers whereas it is more difficult to overcome workers cultural preferences. Financial or material goods can be provided, but the important aspect of integrating and settling into a new culture or living environment depends on the individual worker. In contrast, it is easier for the policy makers to adapt the pension system to encourage migrant workers. As pensions are deferred salaries, it is a matter of offering the worker the best prospects for future pension payments. Pensions can thus be used as a policy instrument to attract working-age persons to jobs elsewhere in the EU. This holds for fixed tenure jobs but especially for temporary jobs and would help fill the labour market vacancies in the EU that are hard to fill. I 
only need to define what best prospects means. Whatever the case, from a worker's perspective, policies that allow the accumulation of pension-savings independent of any EU-employer are the best choice (see Borgy and Chojnicki, 2008; Jarret, 2011).

This brings us to pension portability in its easiest form, the feasibility of pension scheme for an individual worker, mandatory but risk-free saving. I analyse under which parameter settings such a pension scheme breaks even or exceeds the pension needs at retirement. Thereafter, I come back to possible disadvantages or differences of pension systems that are individual or collective or otherwise. This section can be summarized as follows. An individual pension scheme in the EU is conducive to labour mobility, and hence the functioning of the EU labour market, as it helps encouraging workers to cross borders to accept jobs.

\section{Illustrative example of an individual risk-free pension scheme for $\mathrm{Mr} \mathrm{X}$}

This section clarifies the specific meaning in this paper of individual and risk-free pension scheme, by using an example of a representative worker in the EU. I call this person $\mathrm{Mr} \mathrm{X}$.

Mr X starts working at the age of 22 and retires at the official retirement age of 67 years. He starts with an annual salary of $€ 20,000$ that increases at $2 \%$ each year, a rise that is equal to the annual inflation rate during his full 45 years' working life. According to wage bargaining or regulation agreements, $\mathrm{Mr} \mathrm{X}$ saves $7 \%$ of his salary and his employer contributes twice this amount. He and his employer deposit these pension contributions in a tax-free savings account in a bank. The savings account carries Mr X's name, so $\mathrm{Mr} \mathrm{X}$ is the only owner. However, $\mathrm{Mr} \mathrm{X}$ has no access to the funds deposited until he reaches retirement age. This is a so-called blocked account, in that the owner of the account, and anybody else, can deposit money but neither the owner, nor anyone else, can withdraw money until the fixed savings term has passed, coinciding with retirement age. After the fixed term has passed the owner, $\mathrm{Mr} \mathrm{X}$ in this case, is entitled to use the money and, in this example, his savings will have accrued at a fixed interest rate of $4 \%$ each year.

Figure 1 (dotted line) shows the development of the salaries of Mr X during a working life of 45 years, from 22 to 67 years of age. At the age of 66 , his salary is almost $€ 49,000$, so the salary more than doubled due to the $2 \%$ salary-growth during 45 years with year-on-year increases. Figure 1 (dark line) illustrates also the accrued funds in the savings account. At a retirement age of 67 these funds will have reached $€ 720,000$ (as indicated at the right axis). This nest egg 
consists of the pension contributions and the savings due to interest, roughly 300,000 to 400,000 euros. Therefore, the interest savings are higher than the pension contribution, showing the importance of receiving interest over interest over a long period.

Figure $1 \mathrm{Mr}$ X's salaries, pension benefits and accumulation of pension funds in euros

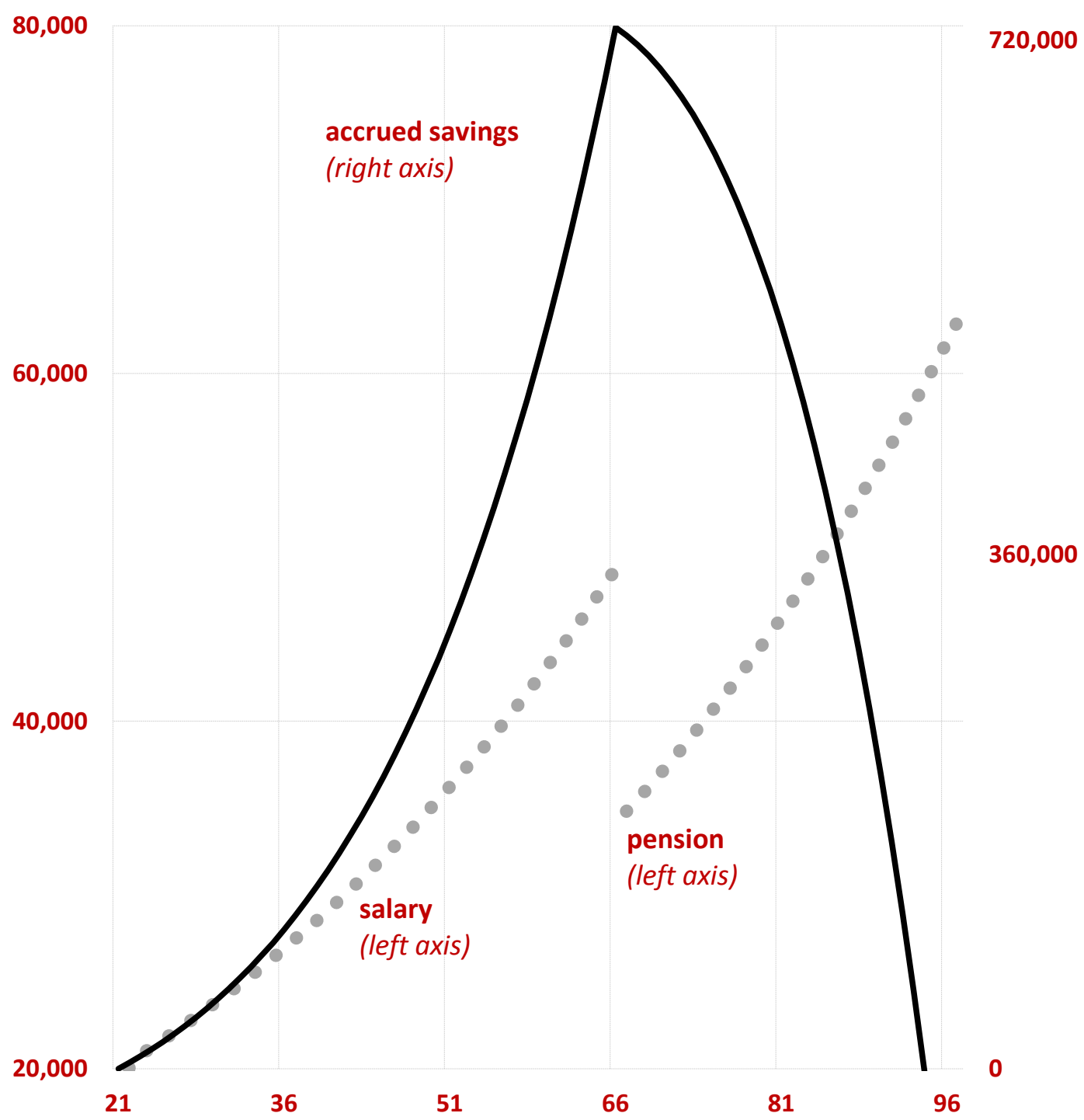

pre-retirement age

retirement age

Source: Author's calculations. 
At the age of 67, Mr X's account is unblocked and he starts withdrawing money at $70 \%$ of his last earned salary being €35,000 (=€49,000*0.7). This is his pension benefit (see line in Figure 1). In the subsequent years, he withdraws the same amount as the previous year but with an increase of $2 \%$ to compensate for consumer price inflation. He can do this up until the age of 94 , when his savings reach zero. As the graph illustrates, the decumulation of his savings takes place in a non-linear way, the reason being that the remaining money in the savings account is still receiving a $4 \%$ interest rate. Because of the fixed long-term savings plan, this interest rate has remained the same over the working and retirement period.

This last feature is important. It indicates that the saved contributions are long-term savings and therefore accrue at a relatively high interest rate. Mr X saves the first pension contribution earned at the age of 22 for 45 years. He saves the pension contribution earned at age 23 also for 45 years, as at the age of 67 he only consumes a small sum of money in view of all the interest accrued on his first salary (earned at the age of 22) this suffices.

Mr X does not necessarily have to work his whole life in the same country or with the same employer. The only relevant parameters in this example are his starting wage $(€ 20,000)$, the length of his working life (45 years), his annual salary increase (2\%), the pension contributions ( $21 \%$ of his salary, of which $7 \%$ contributed by the employee and thus $14 \%$ by the employer), the interest rate on savings (4\%) and the replacement rate at retirement $(70 \%$ of the last earned salary). The outcome is that $\mathrm{Mr} \mathrm{X}$ has secure pension benefits for more than 25 years. Consumer price inflation equalling the nominal increase in the salaries as well as the pension benefits, the real income remains at the same level during Mr X's whole life. To what extent various combinations of these parameters could lead to higher life cycle income outcomes is examined in the next section.

The pension scheme described in this example is individual as $\mathrm{Mr} \mathrm{X}$ possesses all his accumulated funds in a bank account that is only in his name. The scheme is risk-free, due to the fact that Mr X receives a fixed interest rate, independent of financial market or other factors of uncertainty. Furthermore, this scheme is mandatory, as $\mathrm{Mr} \mathrm{X}$ has to save for his pension and cannot use the accumulated funds for consumption purposes before his retirement. Finally, to use the terminology of pension literature and pension policy discussions, the employer and employee have negotiated the pension contributions and not the future pension benefits, so the scheme is a defined contribution (DC) and not a defined benefit (DB). In all these aspects, this scheme is thus rather basic. 


\section{Straightforward specifications and scenario analyses}

This section specifies in general terms Mr X's lifetime income. The resulting inequality is used to show pension outcomes under different parameter settings.

\subsection{Individual risk-free pension savings specification}

The pension contributions saved in year $t$, denoted as $S_{t}$, are based on the initial gross wage, $W_{0}$, that grows with $\delta$ and depends on the rate of pension contributions $\gamma$. It follows that

$$
S_{t}=\gamma * W_{0}(1+\delta)^{t}
$$

With $\rho$ the nominal savings interest rate, the accumulated pension savings are at the end of the working life of $T$ years,

$$
\text { PensionSaving }_{T}=\sum_{t=1}^{T} S_{t}(1+\rho)^{T-t}
$$

Assuming the pension period to be $K$ years, the stream of the pension benefits $P_{t}$ at the age of retirement at period $T$ reads as follows

$$
\text { PensionNeeds }_{T}=\sum_{t=1}^{K} \frac{P_{t}}{(1+r)^{t}}
$$

with $r$ the nominal discount rate. In the example of $\mathrm{Mr} \mathrm{X}$, as discussed in the previous section, this discount rate equals the nominal savings interest rate, so $r=\rho$. I generalise in this specification and allow for the possibility that $\mathrm{Mr} \mathrm{X}$ can dispose of his savings after his retirement for which reason these are no longer long-term savings, which may, therefore, mature at a lower interest rate, hence $r \leq \rho$.

The pension replacement rate, $\mu$, defines the first pension benefit in relation to the last earned wage, $W_{T}$. Adjusted for the consumer price inflation,

$$
P_{1}=\mu * W_{T} *(1+\pi)
$$

and in the subsequent years this first pension benefit grows again at the inflation rate $\pi$, so 


$$
P_{t}=P_{1} *(1+\pi)^{t-1} \text { for } t=2,3 . . K \text {. }
$$

It should hold that individuals save as much money during their working lives as needed for their retirement. I will consider this a requirement, and take the retirement age as measurement point in time, that is year $T$. The total lifetime income $\Omega$ in year $T$, that is the stream of pension savings at retirement age $T$ minus the stream of pension needs during the $K$ retirement years, should thus be positive, that is

$$
\Omega:=\text { PensionSaving }_{T}-\text { PensionNeed }_{T} \geq 0
$$

Substituting (2) and (3) in (5), and subsequently substituting (1) and (4a)-(4b) for $S$ and $P$, respectively, it then holds that

$$
\begin{gathered}
\sum_{t=1}^{T} \gamma * W_{0}(1+\delta)^{t}(1+\rho)^{T-t}-\sum_{t=1}^{K} \frac{\mu * W_{T}(1+\pi)^{t}}{(1+r)^{t}} \geq 0 \\
\Leftrightarrow \\
\gamma * W_{0} *(1+\rho)^{T} * \sum_{t=1}^{T}\left(\frac{1+\delta}{1+\rho}\right)^{t}-\mu * W_{T} * \sum_{t=1}^{K}\left(\frac{1+\pi}{1+r}\right)^{t} \geq 0 \\
\Leftrightarrow \\
\gamma * W_{0} *\left\{(1+\rho)^{T} * \frac{v^{T+1}-v}{v-1}\right\} \geq \mu * W_{T} *\left\{\frac{w^{K+1}-w}{w-1}\right\}
\end{gathered}
$$

with $v:=\frac{1+\delta}{1+\rho}$ and $w:=\frac{1+\pi}{1+r}$.

This last inequality states that the initial pension savings $\left(\gamma * W_{0}\right)$ should precisely match or exceed the pension benefit in the retirement year $\left(\mu * W_{T}\right)$, where this pension saving is accrued to the retirement moment by the first term in curly brackets and this pension benefit is discounted with the second term in curly brackets. Logically, the higher the wage growth $\delta$ during the working life, the higher the accrual of pension funds (term left of the inequality sign). In the same vein, the higher the pension benefit growth $\pi$, the higher the pension needs (term right of the equality sign). However, while the nominal savings rate $(\rho)$ pushes savings upward (term left of the equality sign), higher nominal savings rates after retirement $(r)$ depress the 
pension needs as the remaining savings accrue more quickly. As an extreme case, which is illustrative, assuming $\delta=\rho=\pi=r=0$, it follows that

$$
\gamma * W_{0} * T \geq \mu * W_{T} * K
$$

This implies that the initial pension saving times the number of working years should precisely match or exceed the initial pension benefit multiplied by the number of retirement years. It is the example of a non-growing economy without inflation, wage growth or interest payments.

At second sight, this case is not so extreme as the same inequality holds in case the (wage or price) inflation on income equals the nominal interest rate during the working and the retirement life, that is $\delta=\rho$ and $\pi=r$. This is the case where the return on savings vanishes due to relatively high wage or pension benefit inflation.

As it holds that the pension contribution at the moment of retirement is simply the first earned pension contribution accrued with the wage growth, that is $W_{T}=W_{0} *(1+\delta)^{T}$, substitution in equation (6) gives after division of both sides by $W_{0} *(1+\delta)^{T}$

$$
\begin{gathered}
\gamma * v^{-T} * \frac{v^{T+1}-v}{v-1} \geq \mu * \frac{w^{K+1}-w}{w-1} \\
\Leftrightarrow \\
\frac{\gamma}{\mu} \geq \frac{w^{K+1}-w}{w-1} / \frac{v^{T}-1}{v^{T}-v^{T-1}}
\end{gathered}
$$

Interestingly, this shows that the initial wage plays no role in making the pension savings exactly match or exceed the pension needs. The reason is that a person with a high wage will proportionately have also a high pension benefit, and a person with a relatively low wage a relatively low pension benefit. However, the parameters that indicate the amount of pension contribution $(\gamma)$ and the pension replacement rate $(\mu)$ as a proportion of the initial wage, play a crucial role. Apart from these two parameters, there are six other key parameters.

To summarize, inequality (7) contains the following parameters: 
1. The pension contribution rate $\gamma$.

2. The wage growth rate $\delta$.

3. The length of the working life $T$.

4. The nominal rate of return on savings $\rho$.

5. The pension replacement rate $\mu$.

6. The growth rate of pension benefits $\pi$.

7. The length of the retirement period $K$.

8. The discount rate of pension payments $r$.

In the examples below, I assume that some of these parameters are fixed and I show outcomes for differing values for the other parameters.

\subsection{Pension outcomes under different scenario settings}

Figure 2 shows preliminary findings, where (7) was used at equality. I first show the trade-off between the number of working to retirement years, on the one hand, and the pension contribution to replacement rate, on the other hand. The more years a person works, the lower is the pension contribution rate that this person needs ceteris paribus. In the same vein, the more years a person needs pension benefits after retiring, the lower must be the pension replacement rate ceteris paribus in order for the equality to hold. To illustrate this in an example with numbers, there is a dotted line at the point on the horizontal axis where $T / K=40 / 20=2$ that points at a situation in which the individual worker wants to accumulate pension savings for a retirement period of 20 years during a working life period of 40 years (case A). Following the dotted line upwards, one reaches the dark line, being the isoquant that gives the border between the left area where the inequality (7) does not hold, and the right area where it holds. Following then the dotted line to the left, one reaches the vertical axis at point 0.27 . This is the pension contribution for replacement rate. Assuming that replacement rate is 0.7 , this implies that the pension contribution is $19 \%$. This is less than in the example with $\mathrm{Mr} \mathrm{X}$ in the previous section. Sharing the contributions with the employer and assuming that the employer contributes double that of the worker, it implies that the worker only has to save little more than $6 \%$ of his wage. Thus, a worker with a retirement period of 20 year, and replacement rate of 0.7 , needs to work at least 40 years if he and his employer pay $19 \%$ on pension contributions (by him and his employer together). Or, if he works less than 40 years, they should at least pay a pension contribution of more than $19 \%$. 
If this worker only worked 20 years, followed by a retirement period of 20 years, the contribution would need to rise considerably. In this case $\mathrm{T} / \mathrm{K}=20 / 20=1$ which shows (see the dark line) that the pension contribution should be at least 0.7 times the replacement rate. This is case $B$ in the figure. Assuming again a replacement rate of 0.7 , this implies that pension contribution would have to rise to almost $50 \%$, so little over $16 \%$ for the employee if the employer contributes 33\%. Interestingly, if the employee works 30 years and has a retirement period of 30 years, the situation at the isoquant with the doted line holds. See case C. In this case, the ratio of the pension contribution to the replacement rate drops to 0.6 , and pension contribution of $40 \%$ holds for the replacement rate to remain at 0.7 . Working for 10 years longer is thus proportionally more beneficial as the accumulation of funds significantly increases and this ensures the payment of pension benefits for a much longer period (see also Table 1).

Figure 2 Trade-off contribution-to-replacement rate and work-to retirement years

\section{pension contribution rate / replacement rate}

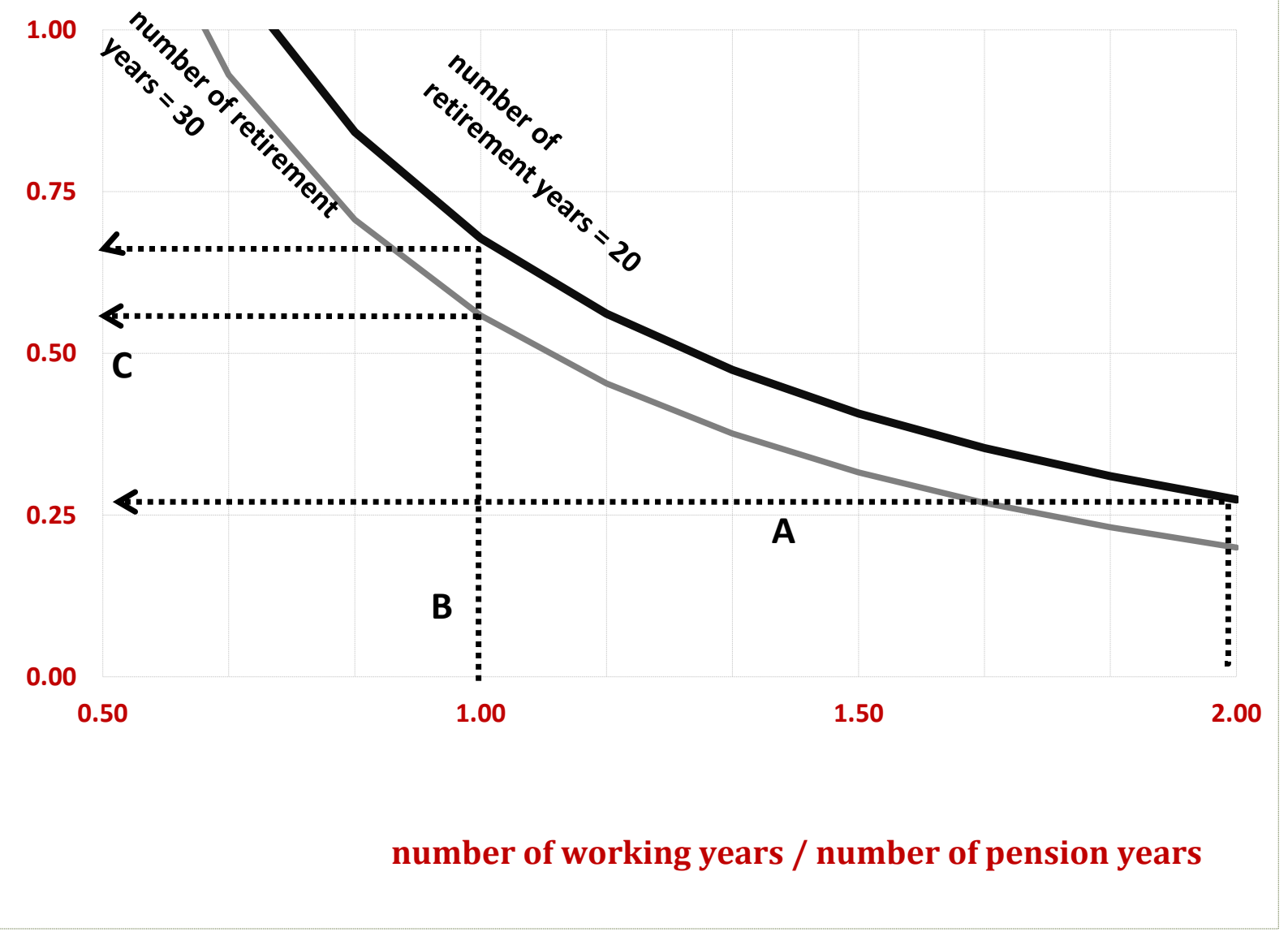

Source: Authors' calculation according to equation (7). 
Table 1 Required pension contribution rate with different parameter settings

\begin{tabular}{|c|c|c|c|c|c|}
\hline savings interest rate & $\rho=0.0$ & $\rho=0.02$ & $\rho=0.04$ & $\rho=0.06$ & $\rho=0.08$ \\
\hline \multicolumn{6}{|c|}{ number of working years } \\
\hline$T=30$ & 0.79 & 0.60 & 0.45 & 0.33 & 0.23 \\
\hline$T=35$ & 0.71 & 0.52 & 0.37 & 0.25 & 0.17 \\
\hline$T=40$ & 0.65 & 0.45 & 0.30 & 0.19 & 0.12 \\
\hline$T=45$ & 0.60 & 0.40 & 0.25 & 0.15 & 0.09 \\
\hline \multicolumn{6}{|c|}{ number of retirement years } \\
\hline$K=20$ & 0.55 & 0.42 & 0.31 & 0.23 & 0.16 \\
\hline$K=25$ & 0.68 & 0.52 & 0.38 & 0.28 & 0.20 \\
\hline$K=30$ & 0.79 & 0.60 & 0.45 & 0.33 & 0.23 \\
\hline$K=35$ & 0.90 & 0.69 & 0.51 & 0.37 & 0.27 \\
\hline \multicolumn{6}{|c|}{ pension replacement rate } \\
\hline$\mu=0.5$ & 0.57 & 0.43 & 0.32 & 0.23 & 0.17 \\
\hline$\mu=0.6$ & 0.68 & 0.52 & 0.39 & 0.28 & 0.20 \\
\hline$\mu=0.7$ & 0.79 & 0.60 & 0.45 & 0.33 & 0.23 \\
\hline$\mu=0.8$ & 0.91 & 0.69 & 0.51 & 0.37 & 0.27 \\
\hline \multicolumn{6}{|l|}{ salary growth } \\
\hline$\delta=0.01$ & 0.70 & 0.52 & 0.38 & 0.28 & 0.19 \\
\hline$\delta=0.02$ & 0.79 & 0.60 & 0.45 & 0.33 & 0.23 \\
\hline$\delta=0.03$ & 0.90 & 0.69 & 0.52 & 0.39 & 0.28 \\
\hline$\delta=0.04$ & 1.01 & 0.79 & 0.60 & 0.45 & 0.33 \\
\hline \multicolumn{6}{|l|}{ pension benefit growth } \\
\hline$\pi=0.01$ & 0.69 & 0.52 & 0.39 & 0.28 & 0.20 \\
\hline$\pi=0.02$ & 0.79 & 0.60 & 0.45 & 0.33 & 0.23 \\
\hline$\pi=0.03$ & 0.92 & 0.70 & 0.52 & 0.38 & 0.27 \\
\hline$\pi=0.04$ & 1.07 & 0.82 & 0.61 & 0.44 & 0.32 \\
\hline \multicolumn{6}{|c|}{ savings rate on pension funds during retirement } \\
\hline$r=0.01$ & 1.07 & 0.82 & 0.61 & 0.44 & 0.32 \\
\hline$r=0.02$ & 0.92 & 0.70 & 0.52 & 0.38 & 0.27 \\
\hline$r=0.03$ & 0.79 & 0.60 & 0.45 & 0.33 & 0.23 \\
\hline$r=0.04$ & 0.69 & 0.53 & 0.39 & 0.28 & 0.20 \\
\hline
\end{tabular}

Source: Authors' calculations based on equation (7).

Note: The standard scenario sets the parameters at $T=30, K=30, \mu=0.7, \delta=\pi=0.02$ and $r=0.03$. Values in bold highlight the cases with pension contribution at or lower than $45 \%$. 
As can be seen in Table 1, which presents an overview of the required pension contribution rate in case of different parameter settings, there are ample cases where this contribution is at or below $45 \%$ (that is $15 \%$ for the employee if the employer pays $30 \%$ ). In the standard scenario the parameters are set at $T=30, K=30, \mu=0.7, \delta=\pi=0.02$ and $r=0.03$. The savings interest rate during the working life varies from $0 \%$ to $8 \%$ in steps of two percentage points, columnwise. As can be seen in the top row, a working life of 30 years and a savings interest rate of $4 \%$ requires a pension contribution of $45 \%$. Increasing the working life to 45 years makes this contribution decrease to $25 \%$. Increasing the working life thus significantly decreases the contribution. At this interest rate on savings if keeping the working life at 30 years, but decreasing the replacement rate from 0.7 to 0.5 of the last earned salary shifts the pension contribution from $45 \%$ to $32 \%$, as follows from the third panel. Combined scenarios are particularly interesting, for instance with this $4 \%$ savings interest rate, the working life of 45 years and a replacement rate of 0.5 makes the required pension contribution falls to only $18 \%$ (not shown in Table 1, but is computable by interpolation). Only cases where the savings interest rate is zero are impossible situations. In such cases the pension contribution would need to be exorbitantly high because the accumulation of funds stagnates. Most other situations would be acceptable, even if $\rho$ is only $2 \%$.

In real life, however, an individual worker cannot influence certain factors. Savings and inflation rates, but also salary growth, are impossible to influence. A worker can however choose to work longer or to agree to a lower pension replacement rate. If it is assumed that a worker does not want to pay together with the contribution by his employer, a higher pension contribution than $45 \%$, he can work out his combination of working life and replacement that meets this requirement. A possibility is that he works 35 years and receives $80 \%$ of his last earned salary as pension benefits after retirement. Or, alternatively, he compromises on $50 \%$ of his last earned salary, in which case he only needs to work 25 years. This can be seen in Figure 3, where the dark line gives all possible combinations of the replacement rate and the number of working years for $\rho=0.4$. Opting for a lower pension contribution rate, of $30 \%$, automatically implies that the worker has to work longer at the same replacement rate or needs to agree with a lower replacement rate at the same number of working years. 
Figure 3 Trade-off between working year and replacement rate at fixed contribution rate

\section{number of working years}

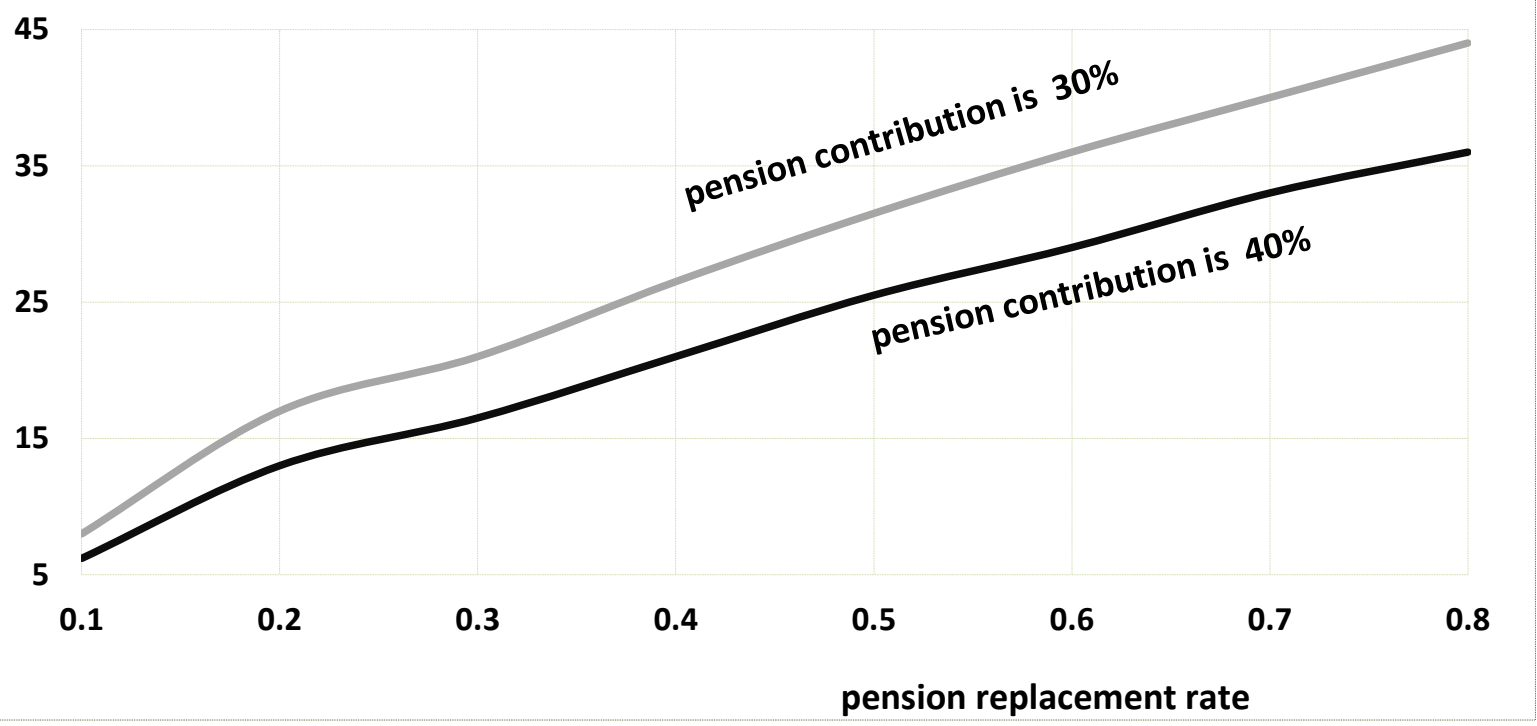

Source: Authors' calculation according to equation (7).

All in all, these calculations show that in terms of feasibility there are various options available to individual workers to ensure that they have enough income during their lives even if savings interest rates are moderate. Moreover, in view of the monetary policy objective of price stability in the European Economic and Monetary Union, inflation and nominal interest tend to move in line with each other so there is hardly a risk of loss of purchasing power. If inflation increases, (policy) interest rates tend to increase, which keeps the value of the savings in the fund constant. For this reason the pension benefits keep their value in real terms.

\section{Benefits of individual risk-free pension schemes for workers}

The example in section 3 showed Mr X's pension scheme during his life and the generalisations made in the previous section once more underline the possibility of pension savings for a long retirement period of even 30 years or more with reasonable pension contributions under various settings of the savings rate, inflation and the replacement rate. From the viewpoint of the worker, there are obvious advantages to this individual pension scheme in comparison with a collective pension scheme. Moreover, also the risk-free characteristic associated with savings has special advantages. 
First of all, the accumulation and, after retirement, decumulation of funds is transparent for the worker. By placing the funds in an individual bank account that the worker owns no one else can interfere, deduct money or change the lump sum apart from the interest payments that are deposited by the bank to the blocked account. This contrasts sharply with the pension schemes around in many EU countries, where workers have no way of seeing the nominal values of their pension schemes are developing during their working life. It is often only when the retirement age approaches, that the worker becomes aware of his pending pension benefits. More transparency not only makes workers more aware, it can also help them decide whether they need to work more or less according their future income wishes (see also Holzmann and Palacios, 2001). In addition, if there are motives to leave bequests for survivors there will be a personal incentive to work more. The lump sum of money that the worker sees accumulating in the bank account is an accurate reflection of what has been earned and what will be paid out once the account is unblocked at retirement.

I like to cite here Sinha (2002), who compares the Latin American individual pension accounts with the US system that claimed to make on average a $6 \%$ rate of return, as it applies here also: Even if the stock markets produce a better rate of return it does not follow that the affiliates of the pension fund, even with 100 percent investment in stocks, will get the same rate of return. The reason is, of course, the ubiquitous management fees that can eat up much (if not all) of the gain. See also Barr and Diamond (2006) on the size of administration costs with individual accounts. See also Hinz et al. (2000). It is furthermore interesting to point out that a $6 \%$ stock market return is overly optimistic. During 1921-1996 this held for the US, but other stock markets worldwide had, including dividends, a far lower return (see Jorion and Goetzmann, 1999).

Second, by saving in a simple risk-free bank savings account, the worker incurs next to no costs. An ordinary bank savings account cost 10 to 30 euros a year in 2010, for complete administration of the account. There is no reason for banks to charge more costs, as in the case of individual risk-free savings accounts they possesses the funds of the worker over a long period until the worker's retirement age due to the blocked character of the account. Using this money for other purposes is at the risk of the bank, and not of the worker. The pension savings should thus also be fully covered by the national deposit guarantee system.

As investment in equity or bonds does not take place, there are no trading costs or additional costs for governing a portfolio of investments. Average operational costs of collective pension funds in 14 countries of the EU, ranging from $0.1 \%$ (Denmark, Portugal) to more than $1.0 \%$ 
(Czech Republic, Spain) of the total assets (see Graph 7 in Peeters, 2011). The simple average is $0.5 \%$ and thus relatively high in comparison with the fixed costs of 10 to 30 euros a year for a bank savings account. These costs significantly depress returns (comparable with our $\rho$ in the previous section). Moreover, the OECD does not yet have information about the costs made in the remaining 13 countries of the EU and this may indicate that the average costs in the EU are even higher.

Third, with individual pension schemes, workers will no longer be subject to the whims of a government or other pension fund managers during or after retirement in case of an. This independence is a valuable advantage that is not part of most pension schemes in the EU. If workers are part of a scheme governed by the government, the pension funds risk being used to fill the holes of public finance deficits, although this is not ethical and sometimes even illegal. However, history has shown that ministers of finance, in need of funds and under pressure by the public can be tempted to use pension funds to pay for current expenditures. The dire state of public finances related to the sovereign debt crisis, such as in the economies at the rim of the EU, increases the likelihood of this happening (see Van Groezen et al., 2009). If a government is likely to need the pension funds to use for public funding, the greater the incentive to keep its workers in the dark about the state of their pension schemes. In countries where other funds' managers govern the accumulated sum of money there are also rules that these managers can change in the course of time. For instance, governments may decide to stop indexing the growth of the pension benefits at consumer price inflation, or may change the pension replacement rate. In times of financial crises, incurring depressed investment outcomes, or an ageing population, where funds' expenditures exceed income, there is pressure on fund managers to change the rules. The change of rules is particularly problematic when it occurs after retirement because the worker is unable to replenish income by working (more) to save more.

The conclusion of these three benefits for the worker is that it is better to be safe than sorry. It is better to take the safer option and have a simple savings account where the accumulation of funds during a working lifetime is transparent, in order to be able to adjust labour market participation if needed. It is better to be aware of the costs and outcomes and have low investment costs with a fixed return rather than to incur unknown costs in exchange for the possibility of high returns (such as investments in equity) and be sorry that pension benefits turn out to be lower than expected on retirement. Last but not least, being independent of governments or other fund managers, guarantees no unpleasant surprises will occur at a time when the individual worker is no longer able to augment income. 


\section{So why not implement an individual risk-free pension scheme?}

After examining the ability to pay and the benefits of an individual risk-free pension scheme as outlined in the previous sections, the counterarguments are now discussed. What reasons could be given why an individual should not favour an individual risk-free pension scheme?

First, investing in a collective scheme with non-risk free investments can deliver higher returns and as a consequence lower pension contribution are required in order to reach lump sum at retirement. However, it has been shown that the return on pension contributions deposited by the worker and the employer in an individual savings account is on average no more than $2 \%$ points under the return on the same contribution deposited with a government or other pension fund (institutional investors, pension funds, insurance companies). Looking at the gross returns in a historical perspective, collective funds only rarely attained an average return of $6 \%$ whereas, even in times of worldwide low interest rates, the interest rate on a long-term savings account (10 years or longer) was 4.0\%. Saving deposited in a blocked bank account where the funds are not accessible until retirement, often means even longer fixed terms and thus even higher interest rates. Apart from Denmark, the global recession years have led to dramatically low returns on collective pensions: of $0.8 \%$ on average for these 16 EU countries (see Figure 8 in Peeters, 2011). This evidently shows that the risk of missing-out on the higher returns of the more risky investment is outweighed by the risk of unacceptable losses (see Sinha, 2002).

A second argument against individual (risk-free) pension schemes could be an unwanted shift away from the social insurance concept and the tacit solidarity across and within generations. For instance, there is no insurance against the risk of the loss of human capital through illness. However, these insurances more related to sick pay that either the employer or the government is better able to carry. In most of the developed economies, these insurances are part of the wider social security system and are not covered by pension funds. Insuring the loss of earnings through illness is expensive. Moreover, this solidarity is a social issue and not necessarily the responsibility of the individual employee. While collective pension schemes can relieve borrowing constraints and enable intergenerational risk sharing, they usually imposes uniform rules on heterogeneous participants (cited from Bovenberg et al., 2007; see also Barr and Diamond, 2006). Pension saving over a lifetime, however, is largely in the hands of the worker. Workers should not be punished dis-proportionally more than non-workers, in view of demographic developments and for the sake of the functioning of the common market single currency. Moreover, as Holzmann and Palacios (2001) argue, individual accounts are a better way of dealing with labour market incentives and changing family patterns, such as divorces, 
multiple marriages or relationships over the life cycle, widowhood, and the resulting need for independent old-age security for non-working partners. Under an individual account system, accumulated resources can easily be split after a divorce for the period marriage, aggregated with own and prior contributions and interest received, and supplemented by public resources in a transparent manner (for instance, for periods of child rearing).

A third argument against an individual (risk-free) pension scheme is the risk of cover and longevity. In the examples presented in the previous sections, one of the assumptions was that workers have perfect foresight and also know how long they will live. If pension savings accrued during a working life are estimated to cover 20 retirement years and the worker lives much there will clearly be a financial gap at an age when this is difficult to resolve. This is true, but it is a surmountable problem. Policy makers could impose the life-expectancy age as a guideline for workers and the few people who surpass this set age could be entitled to a special social security benefit. Alternatively, workers could be required by law to save for a minimum of 30 years retirement. This period is achievable, under reasonable parameter settings, as followed from the calculations in section 4 .

A fourth argument against individual (risk-free) pension schemes is that some people are not capable of doing their own financial planning for, such a long period as a lifespan. This objective is often raised but, in my view, is rather weak. Learning to plan is an important skill and leaving this to others is generally more costly and in case of risk-free saving as outlined in the previous sections, there are only few parameters to decide upon (see also Milevsky, 2009; Pozen and Hamacher, 2011). The pension contribution rate, as well as the workers and employers' share, should be part of the wage-negotiation process. The pension scheme is still mandatory, as savings have to take place and the money on the savings account is inaccessible (blocked), so these are no decisions to make. The worker does not have to make any investment strategy decisions, as the bank will save the worker's funds risk-free at the highest interest rate for each payment until retirement.

There were no other arguments against individual risk-free pension schemes in comparison with collective riskier schemes. I abstain here from a term life insurance, which benefits a worker's survivors. In case a worker dies, the individual risk-free saved funds are anyhow at the disposal of the survivors at the retirement age of the worker. A term life insurance is extremely costly (up to $2.5 \%$ of the contributions) but often not needed, such as in case the survivor is able to work or entitled to other (social security) funds or if there are no survivors. And general risks as the inflation risk affect both schemes. 


\section{Summary, conclusions and policy recommendations}

In the past, the economies of the European Union all started building collective pension funds. This emerged at a time when there was a great need for solidarity and intergenerational risksharing. The move towards these two national goals, separately or in combination, was in place well before the start of the European Economic and Monetary Union.

However, times have changed. The European Union now also has a monetary union. The loss of national discretion on monetary policy, exchange rates and interest rate instruments, and the absence of a common fiscal policy means that the functioning of the labour market is of paramount importance. In the absence of a fully functioning fiscal union, only labour mobility can cushion the effects of asymmetric shocks that have hit some but not all of the economies of the monetary union.

In addition, demographic developments mean that the member states are ageing. Moreover, working-age populations are shrinking while there are more and more elderly dependents in the economy. This puts pressure from demographic change on the working-age population. The working-age population has to adapt in order to provide the needs in terms of goods and services of an aging society, and have to work more in order to pay the income for the larger generation of retirees. In addition, workers should not forget to save for their own retirement. To help them achieve this, the working-age populations should be given incentives to be flexible in the labour market.

Although labour mobility in the European Union has significantly risen, it is still low. One of the impediments is the non-portability or costly portability of pension schemes for a worker across the borders. It would be better to facilitate and give EU workers incentives to cross borders for work. This is advantageous to the functioning of the European Union and to absorb the impact of demographic change, as explained above. In comparison with other factors that impact labour mobility, pensions could be a feasible and effective policy instrument for the EU policy makers to increase mobility.

This paper argues that there are many arguments to move towards individual risk-free pension schemes, in particular for workers that cross borders but not exclusively. This type of pension scheme is by definition portable across EU-borders. Although it does exists on a very small scale, the majority of employers in the EU force their workers into collective schemes. Worker cannot opt-out, unless they quit their job. However, once a worker leaves a job, transporting any accumulated pension across the EU borders is almost impossible or extremely costly. 
This idea of an individual risk-free pension schemes hinges on the balance between government intervention and freedom of choice, which is often seen as social versus liberal, respectively, in the literature. Currently, most first-pillar (but also second-pillar) collective schemes accept a government-prescribed straightjacket. And if it is not the government then it is an intermediary insurance or pension company making the choices for the employee. The individual risk-free scheme promoted here does not fit in this system. Neither does it fit in the freedom of choice category, as paying pension contribution is still mandatory and there is no liberty in managing the funds due to the risk-free savings. The funds, however, remain in the hands of the worker and are thus transparent and portable.

Apart from enhancing the labour market mobility, there are two other macroeconomic benefits from individual risk-free pension schemes. Firstly, the individual character of the scheme will create the right incentives and make non- or partly participating working-age persons aware of the need to participate and save more funds in order to make ends meet after retirement. This incentive to participate (fully) in the labour market could lead to more job vacancies being filled. Secondly, individual pension accounts can improve the social insurance aspect of public pension schemes, make them financially sustainable and even more redistributive (see Holzmann and Palacios, 2001).

Furthermore, this paper shows that a worker can easily achieve a reasonable pension benefits over a long retirement period of 30 years if employers contribute their share of the pension savings. For workers retiring at the age of 67,30 retirement years should take them well beyond normal life-expectancy. The nominal pension benefit is thus, without interference of others, apart from a solid bank account, fully guaranteed.

I further show in this paper that an individual risk-free pension scheme has three main advantages for the employee. First, workers can clearly see what they will get. Second, the financial costs are next to nothing. Third, independent of the whims of government or other fund managers and workers will receive all the benefits accrued earned their lifetime.

As the difference between market returns and risk-free bank savings account has diminished over the last decade and public finances are in trouble, there are no arguments from the return point of view either to validate forcing workers into collective risky investment schemes.

A remaining question to be answered concerns what actions are needed by the EU policy makers to establish the EU-wide implementation of individual risk-free pension schemes. This question is easy to answer. Each EU-citizen who takes a job work across an EU border - but 
within the EU - should be entitled to a long-term interest-bearing bank savings account that accumulates the monthly pension contribution. This contribution comes from the employee and the employer, where their precise shares should be part of the job negotiation process. The savings account should be an EU-wide tax free, long-term interest bearing account that is blocked until the moment this EU-citizen reaches the retirement age, let us say, of 67 . This account is called blocked as no money can be withdrawn until the owner reaches the age of 67, though it should be visible at all times to the owner of the account, so that the contribution payments of the employer and interest payments by the bank can be followed in the course of time. The banks that offer these bank accounts charges only minor costs, as they have huge sums of long-term savings in their possession for which they only have to pay a long-term interest rate. This interest rate should be as high as possible, for each payment in the account from the payment moment until the retirement age. The total funds on these pension schemes accounts should be part of the national deposit guarantee systems, as they are risk free. After the age of 67, the EU-citizen receives a monthly payment from this accumulated wealth for a predetermined number of years. As our calculations show, thirty years is feasible, so until the age of 97 . For those exceeding this age, a safety net should be in place.

At the discretion of the national governments, the EU nations can follow this stepwise implementation of the individual bank-savings-account pension accumulation in the EU. 


\section{References}

1. Adema, W. and Ladaique, M. (2009). How expensive is the welfare state? Gross and net indicators in the OECD social expenditures database (SOCX). OECD Social, Employment and Migration Working Papers 92.

2. Arza, C. and Kohli, M. (2008). Pension reform in Europe: Politics, policies and outcome. New York 109-131.

3. Barr, N. and Diamond, P.A. (2006). The economics of pensions. Oxford Review of Economic Policy 22(1):15-39.

4. Borgy, V. and Chojnicki, X. (2008). Labor migration: Macroeconomic and demographic outlook for Europe and neighbourhood regions. Economie Internationale / International Economics 3(119):115-153.

5. Börsch-Supan, A. (2006). European welfare state regimes and their generosity towards the elderly. The Levy Economics Institute of Bard College Working Paper 479.

6. Bovenberg, L., Koijen, R., Nijman, T. and Teulings, C. (2007). Saving and investing over the life cycle and the role of collective pension funds. De Economist 155(4):347415.

7. Cavelaars, P. and Hessel, J. (2007). Regional labour market mobility in the European Union: Adjustment mechanism or disturbance? DNB Working Paper 137.

8. European Commission Directorate-General for Employment, Social Affairs and Inclusion and Eurostat, the Statistical Office of the European Union (2011). Demography Report 2010 - Older, more numerous and diverse Europeans, Staff Working Document.

9. European Commission Directorate-General for Employment, Social Affairs and Inclusion (2010a). Green Paper - towards adequate, sustainable and safe European pension systems, SEC(2010)830.

10. European Commission Directorate-General of Economic and Financial Affairs (2010b). Progress and key challenges in the delivery of adequate and sustainable pensions in Europe, European Economy Occasional Papers 71.

11. Hinz, R., Rudolph, H., Antolin, P. and Yermo, J. (eds.) (2010). Evaluating the financial performance of pension funds. World Bank.

12. Holzmann, R. and Palacios, R. (2001). Individual accounts as social insurance: A World Bank perspective. World Bank Discussion Paper 0114.

13. Huber, P. (2004). Inter-regional mobility in Europe - A note on the cross-country evidence, Applied Economics Letters 11(10):619-24. 
14. Jarret, P. (2011). Pension reforms in Poland and elsewhere: The view from Paris. Center for Social and Economic Research (CASE) Network studies \& analyses 425, Warsaw.

15. Jorion, P. and Goetzmann, W.N. (1999). Global stock markets in the twentieth century, Journal of Finance 54(3):953-980.

16. Jousten, A. and Pestieau, P. (2002). Labor mobility, redistribution and pension reform in Europe. NBER Chapters: in Social security pension reform in Europe 85-108 with comments from Michael Burda.

17. Milevsky, M. A. (2009). Are you a stock or a bond? Create own pension plan for a secure financial future. Financial Times Press, ISBN 978-0-13-712737-5, 240 pages.

18. Organisation for Economic Cooperation and Development (2011). Society at a glance.

19. Peeters, M. (2011). Better safe than sorry - Individual risk free pension schemes in the European Union - Macroeconomic benefits, the mobile working citizen's persepective and "why nots". MPRA Working Paper 33571. An extended version of this article.

20. Peeters, M. and Groot, L. (2011). Demographic change across the globe - Maintaining social security in ageing economies. EERI Research Paper Series 18/2011. Forthcoming in World Economics 13(2).

21. Peeters, M. and Den Reijer, A. (2012). Wage formation, wage flexibility and wage coordination - A focus on the wage impact of productivity in Germany, Greece Ireland, Portugal. Spain and the United States, MPRA 31102.

22. Pozen, R.C. and Hamacher, T. (2011). The fund industry: How your money is managed. Wiley and Sons.

23. Razin, A. and Sadka, E. (1999). Migration and pension with international capital mobility. Journal of Public Economics 74(1):141-150.

24. Sinha, T. (2002). Can Latin American's experience teach us something about privatized pensions with personal accounts? Paper presented at Retirement Implications of Demographic and family change symposium in San Francisco.

25. Van Groezen, B., Kiiver, H. and Unger, B. (2009). Explaining Europeans' preferences for pension provision. European Journal of Political Economy 25:237-246.

26. Zaidi, A., Grech, A.G. and Fuchs, M. (2006). Pension policy in EU25 and its possible impact on elderly poverty. LSE STICERD Research Paper no CASE 116. 